\title{
Mosques as Bases in Scientific Flourishing Movement During the Lifetime of the Prophet (PBUH) and the Two-Rightly-Guided Caliphs
}

\author{
Mahmood Atharizadeh \\ BLVD Qutb Ravandi \\ Department of English Language, Kashan University of Medical Sciences \\ Kashan, Iran \\ Tel: 009-855-540-021Ｅ-mail: m.atharizadeh@yahoo.com
}

Received: December 1, 2020

Accepted: January 13, 2021

Published: January 30, 2021

doi:10.5296/iss.v9i1.18319

URL: https://doi.org/10.5296/iss.v9i1.18319

\begin{abstract}
Scientific movement in Islam commenced with the revelation of the first verses of Quran to the Prophet (PBUH) when He was ordered to Read. Then his divine mission, particularly, scientific one was started. The sacred places for fulfilling his scientific mission were mosques built by him and his companions in Mecca and Medina as well as other cities throughout Islamic territory.

Unlike other temples, mosques from their early establishment played numerous functions like ritual, political, social, and educational ones, hence, the Prophet (PBUH) and His companions paid most attention to teach their followers and made them familiar with Quran and Islamic sciences in sacred places, mosques. The aim of the paper is to discuss scientific activities performed in different mosques during the lifetime of the Prophet (PBUH) and the first twoRightly-Guided Caliphs.
\end{abstract}

Keywords: Scientific movement, Mosques, the Prophet, Caliphs 


\section{Introduction}

Scientific Movement in Islam was accompanied with the beginning of the revelation of the first verses of Quran as the Prophet was ordered to Read.

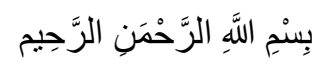

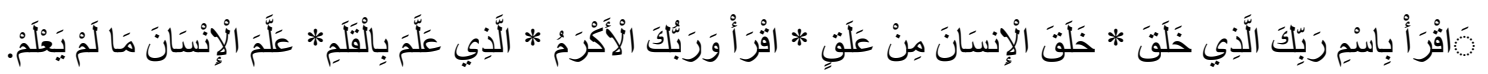

In the name of God, the Merciful, the Compassionate.

1). Read! In the Name of your Lord, Who has created (all that exists),

2). Has created man from a clot (a piece of thick coagulated blood).

3). Read! And your Lord is the Most Generous,

4). Who has taught (the writing) by the pen [the first person to write was Prophet Idrees (Enoch)],

5). Has taught man that which he knew not.

The Quran uses repetition to embed certain key concepts in the consciousness of its listeners. Allah (God) and Rab (the Sustainer) are repeated 2800 and 950 times, respectively, in the sacred text; Ilm (knowledge) comes third with 750 mentions (23) which indicates its significance and holiness. Also, it suggests that there is no conflict between religion and science as some theorists claim. The prophet Muhammad (SAW) commanded knowledge upon all Muslims, and urged them to seek knowledge as far they could reach, and also to seek it all times. Ali ibn Abu Talib, 4th Caliph (may Allah be pleased with him), once said, "I would be slave of a person who teaches me a letter" accentuating the importance of knowledge. Following these commands and traditions, Muslim rulers insisted that every Muslim acquire learning and they gave considerable support to institution and learning in general. This contributed to making elementary education almost universal amongst Muslims.(23)

Besides, Chapter AL-Alaq (The Clot) revealed to the Prophet indicates this significance as

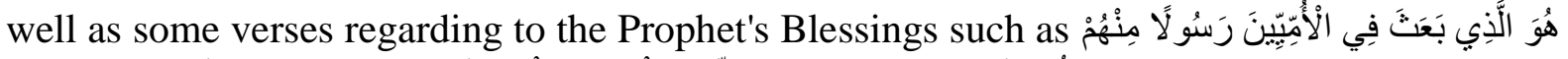

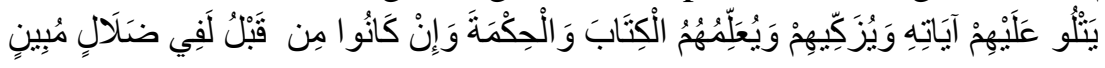

He it is who has sent among the uneducated a messenger from them, to recite to them His signs to purify and to teach them Scripture and Wisdom, and surely they were in plain error before that". This verse emphasizes learning and obtaining knowledge and the priority of science in Islam. As another historical event which indicates the significance of science was the Battle of Badr happened in the second year of Hijrah in which Muslims gained victory against their enemies. The men whom captured in the battle and had the capacity of writing and reading were ordered by the Prophet, each of them, to teach 10 children then be released which indicates the importance of knowledge in Islam. The best places for fulfilling this duty were mosques. Unlike other temples, mosques in their early establishment were not only places for worship, but built for numerous functions and considered as institutes for teaching illiterate people. From educational point of view, they have contributed in forming scientific 
circles among numerous scientists too. The aim of this study was to clarify the scientific role of mosques in spreading Islamic sciences as well as acquainting new Muslims with them and emphasizing its roles in promoting scientific movement in Islamic and non-Islamic territories.

\section{Methodology}

Some Scientific articles and Islamic texts were reviewed to prove the priority of learning science in Islam and its movement from the first revelation of Quran to the Prophet (PBUH).

\section{Literature Review}

\subsection{Educational Activities in Masjid al-Haram}

Although mosques are essentially established for worshipping the One God, they play numerous roles in educational, propaganda, social, and political affairs. Masjid al-Haram, the most famous and sacred mosque in the Islamic world, had multifunctional activities during the lifetime of the Prophet (PBUH) and the first two- rightly-guided Caliphs.

During the Prophet's inhabitancy in Mecca When the city was conquered by the Prophet, the messenger of Allah (PBUH) in $8 \mathrm{AD}$, The mosque was cleansed of the idols and used as a sacred place for worshipping as well as a great educational institution for disseminating Islamic teachings. Thereafter, training, teaching, and educational activities were started there and great persons such as Otab-ibn Aseed, Mu'az-ibn Jabal and Abu Musa Ash'ari whom were appointed by the Prophet as governors of Mecca respectively as well as religious-affairs teachers, taught Quran and Islamic Jurisprudence to neo-Muslims. Then, during the lifetime of caliphs as well as Amavid era, it became one of the significant centres for Islamic Sciences.

\subsection{Masjid al-Nabi}

The mosque was constructed by the Prophet in Medina after his early migration there. It was not only used as a main gathering place for Muslims to perform religious obligations, but it was considered as the first centre for scientific, political, social, and global Islamic movement. In fact, fundamental bases for establishing Islamic government were constructed in Al-Nabavi mosque and principles as well as foundations of Islam were delivered there to the world.

The mosque had numerous activities during the Prophetic mission like ritual, educational, literary, political, and social ones .So, its functions were not limited to worship. Since the paper aims to discuss the importance of scientific movements, we brief our discussion on it to highlight its significance in Islam.

\subsubsection{Educational Activities in Masjid- Al Nabavi}

Although most mosques during the lifetime of the Prophet (PBUH) had educational activities (22), Nabavi Mosque was considered as a principal centre for teaching Quran and Islamic Jurisprudence, because the Prophet himself ( as the great human teacher and messenger of knowledge )engaged in teaching and guiding Muslims .After performing congregational prayers as well as other suitable opportunities, the Prophet gathered the prayers in special 
scientific circles for teaching Quran and religious affairs.

Safvan Ibn-Qasan narrated that one day I told the Prophet I entered the Mosque for learning and acquiring the knowledge. The prophet replied: Good job as you are seeking science and wisdom.

The Prophet recommended his companions to ask questions, to write, and memorize scientific subjects He was teaching. It was narrated that the Prophet said: "The best way for treating ignorance is to make inquiries". (26)

Also, Omar Ibn-Shoayb narrated from his ancestor who said:" I told the Prophet that do I write what I hear from you? He replied "yes".......

For encouraging His companions to memorize what they learn, the Prophet said:" God blesses a man who hears me an utterance then memorize it and convey to others (12).

Ibn- Majeh in his book, Sonan, narrated that the Prophet said:"Who enters my mosque ,Masjid al-Nabi, with the intensive of learning knowledge or teaching it to others is such as a man who strives hard in the cause of God....(20)

It should be noted that meetings as well as circles for teaching Quran and Islamic jurisprudence were held in the Mosque over most daily times even at nights and in addition to the Prophet himself, the great of companions like Ali, the forth caliphate, Ibn-Masud, Zeyd Ibn-Sabet, Obey Ibn-Kaab.and so on taught Muslims the Book ans Islamic jurisprudence. (10)

It has been said that recitation of Quranic famous readers in the Mosque was too loud that no other voice could be detected. For this, the Prophet ordered them to recite it a little slower for preventing any error. (25)

One night, the recitation instigated the Prophet to inter the Mosque. As He came saw the Salim Mawla ibn Abu Hudhayfa was reciting the Quran loudly and nicely, then, in order to encourage him to learn Quran, the Prophet said him:" Praise be to God who put you amongst my nation a good man such as you. The Companions of Sufah who lived in the Mosque taught Quran there and their teacher was Ubadah ibn al-Samit. (8)

It is concluded that Al-Masjid an-Nabawi In Medina from its establishment was a principle place for teaching Quran and the Prophetic Hadith as well as the main centre for preaching and guidance as well as a school for teaching jurisprudence and science.

\subsection{Masjid al-Quba}

It was the first mosque constructed by the Prophet (PBUH) after his migration from Mecca to Medina in a place named Quba near the south of Medina. (20)

It should be noted that the mosque was not only used for ritual activities, it was for Islamic teaching and learning too. Makhool narrated that ten of the Prophet's companions said me that they were studying in Quba mosque in the presence of the Prophet. While leaving the mosque, He said the companions that what you need to know learn .God reward you provided 
what you have learnt apply it in your daily life (25).

\subsection{Literary Activities}

It should be mentioned that scientific activities in the Mosque were not limited to teaching Quran and religious affairs, furthermore, literary associations were held there and great Arab poets as well as lecturers were composing their poems and preaching their sermons in the presence of the Prophet since He praise poems which promote spiritual and ethical values .(8)

Jaber bin Samra, one of the Prophet's companions stated that I saw the Prophet more than one hundred times in the Mosque while His companions were discussing literary poems concerning Jahiliyyah, the period of time and state of affairs in Arabia before the advent of Islam in 610 CE.He smiled.

It has been said that one day Kaab Ibn Zuhayr entered the Prophet in the Mosque and converted Islam then stood up and composed a poem relating to the Prophet's characters and his personal circumstances, the Prophet heard and liked it.(19)

Maghazi (Waqidi) a historian and biographer of the second and third centuries AH, has recorded that the Prophet instructed his companions to place a pulpit for Hassan Ibn Thabit, one of the greatest Arab poets before the advent of Islam and at the beginning of the Islamic period, to recite his poets on it. (17) This is another historical document indicated that Islam and its messenger attached great importance to valuable poetry which is a part of literary honors of every nation and the Mosque was a poetry reading circle for poems and literatures during the lifetime of the Prophet (PBUH). It also had multi-functional roles in numerous dimensions.

\subsection{Khaif Mosque, Located at Mina in Mecca}

Numerous mosques were constructed during the lifetime of the Prophet in Medina and Mecca, in which, in addition to performing prayer, scientific and cultural activities were usually performed. Hence and in brief two of them are mentioned here.

Kkaif Mosque. This is the oldest mosque located in Mina, Mecca. the most important mosque in Mena region whose construction dates back to Adam (15).It was the worshipping place for many divine Prophets.(6) The Prophet prayed during every Hajj rituals in the mosque and in His Farewell Pilgrimage He recited a sermon which indicates the educational activities in the mosque.(6)

\subsection{Teachers of Religious Affairs}

As it was stated, the Prophet was the first one who invited Muslims to seek knowledge and acquire science and He himself was the one who begun teaching them.

By ongoing effort and constant endeavor He spend in spreading Islamic sciences he was able to teach and train numerous eminent students who became then the founders of Islamic sciences . They as companions of the Prophet commenced from the beginning their educational missions through teaching Quran and religious principles and obligations to neo-Muslims . They taught and discussed affairs alignment to Islam and divine matters at the 
prophet era.

They were sent as propagators to numerous cities while the prophet was in Mecca ,so that, before immigration to Medina He sent Musab bin Omair bin Hashim and Abd-Allah ibn Umm-Maktum of the Companions of the Prophet (pbuh) and the forerunners of Islam there to teach Quran and religious affairs to neo-Muslims inhabited in Medina.(25)

After prophetic migration and spreading Islamic territory as well as penetrating Islam in most Arabian Peninsula, the need of Muslims there to Quran's teachers and Religious scientists was increased. Therefore, the Prophet appointed one or group of companions for each city to teach and learn Islamic rituals. They went to the cities and their duties were only to teach them. As an instance, after the conquest Mecca, the Prophet appointed Muadh ibn Jabal and Abu Musa Ashaari there as teachers of Quran and practical and worshipful Islamic commands. Also, some of the companions who were appointed as the Prophet's agents had the obligation of acquainting educational missions to neo-Muslim.(17)

\subsection{Scientific Movement During the Lifetime of the First Two Rightly-Guided Caliphs}

After the migration of the Prophet to Mecca and construction of Masjid al-Nabi there, other mosques were gradually founded in Mecca and its different regions either by the Prophet himself or by His companions. In fact, Muslims with their peculiar belief learnt through Quran and Prophet's guidance, showed highly eagerness in constructing, maintaining, and keeping active mosques, and actively participating in their ritual, social, and educational programs. Therefore, in regions where their people came to Islam, constructing mosques were not only considered a religious obligation, but also were a principle place for protecting Muslim's social and political affairs.

According to historical documents, the second Caliph ordained his governors in Basra and Kofa (Iraq cities),Syria and Egypt to found a central mosque for people to gather and perform Friday Prayer.(10) So that, It did not take a long time that in every city and rural area numerous mosques were built. The process of building mosques in Muslims' cities was so high that merely in Baghdad there were thirty thousand mosques during the third century AD.(24)

It should be noted that most mosques from their early construction were used as first educational institutions in Islamic territories and they were still active in the field of teaching and learning in other periods. Most scientists among companions and their followers who migrated to cities for conquering them or were sent out there as governors or teachers of religious issues by the Caliphs inhabited in the cities and started teaching Quran as well as Islamic jurisprudence to neo-Muslims. Historical contests have mentioned a large numbers of them like Abu Musa Ashaari,(16)Abu Najid Imran bin Hussein Khazaei,(7) Abdullah bin Abbas,(2) Hasan al-Basri,(21) Abdullah ibn Masud,(2) etc.

\subsection{Central Mosque of Basra}

The mosque was founded by Abu Abdullah Utbah ibn Ghazwan Harithi Mazni, the first governor of Basra appointed by the second Caliph. 


\section{Macrothink}

It was later considered one of the general Mosque in Basra.(5)

It was testified numerous scientific activities such as Arabic syntax, Theology, and religious Jurisprudence in the first two- guided-rightly Caliphs era. According to most historian, Abu al-Aswad al Du'ali, the founder of Arabic grammar and the poet of early Islam (16 AH), begun his educational activities in Basra Mosque. (sirafi, 1956)

Concerning to its educational activities, it should be noted that this general mosque was one of the principal place for teaching and dispersing early Islamic sciences in which great scientists like Hassan Basri, Jafar bin Hassan, Ibn Sirin, Abu Najid Imran bin Hussein Khazaei etc were teaching religious sciences.

Mu'tazilite movement, the first Islamic school, which had a significant role on The intellectual-political currents of Abbasid era originated from Basra general mosque.( 13)

\subsection{Madain Mosque}

It was established in Madain, the capital of Iranian Kings. When Muslims conquered Iraq during the $14^{\text {th }}$ to $16^{\text {th }} \mathrm{AH}$, they renamed Ctesiphon,

The capital of the Parthians and Sassanids, as Madain in which The magnificent Sassanid palace was located(Guy) and converted Kasra Arch, The largest brick arch in the world, into mosque with slight change.(4)

In the day of conquest, Sa'd ibn Abi Waqqas along with the Muslims entered the Arch then performed the congregational prayer. Izz al-Din ibn Athir in his book "The Complete History", has narrated: When Sa'd entered the white Arch of Sassanid read this verses:

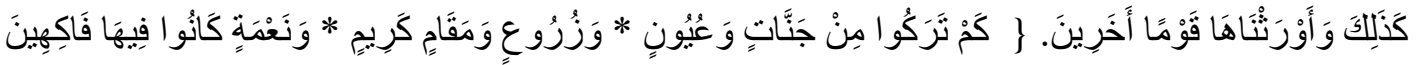

What gardens and springs did they leave behind?

And good fields and places

And the blessing which they enjoyed

[Yes] it was, and We gave it to other people (Chapter 44/Verses 25-28)

then performed the prayer of victory. And since inhabited Basra, he performed the first congregational prayer which was considered the first one in Iraq.(4) Concerning its educational and propaganda activities, it should be noted that since two great of scholars from Prophets' companions i.e. Hudhayfah ibn al-Yaman and Salman al-Farsi were the governors Basra respectively their duties were not limited to Administrative and political affairs but they should teach and propagate religious affairs and Jurisprudence.(9)

Therefore, the mosque in addition to usual activities political and propaganda ones were carried out.178

\section{Conclusion}

According to Quran and Islamic texts, science is a sacred term repeated in different forms in 


\section{Al Macrothink}

Issues in Social Science

ISSN 2329-521X

2021, Vol. 9, No. 1

Quranic verses by which a man can obtain knowledge concerning himself and numerous facts about the universe and the world thereafter. Hence, acquiring it is an obligation for any Muslim and the first verses revealed to the Prophet (PBUH) indicate the fact. Indeed, the Prophet (PBUH) by teaching and training experienced missionaries could present the reality of Islam and Quran whose first recommendation were learning knowledge and spreading it and the most advancement Muslims gained during the first decades of Islam was in the light of the endeavors of those missionaries who bestowed most struggles for spreading real knowledge. Although mosques had numerous activities throughout the Islamic era, the first and significant activities performed in there were teaching and learning and the Prophet (PBHU), Caliphs, and other companions paid most attention to teach, then, to learn others. These facts indicate there is no conflict between science and religion in Islam.

\section{Recommendation}

More studies and further investigation on Islamic as well as non-Islamic historical sources are recommended to shed light on numerous dimensions of mosques, particularly, on scientific movement during the lifetime of the Prophet (PBUH) and the first two-rightly-guided Caliphs.

\section{References}

Abu, D. (n. d.). Sunnah of Abu Dawud.

Al Baladhuri, A. ibn-yahya. (2002). Fotuh al_Buldan. Dar Kitab Al-Alamiya, Beirut.

Al-Athir, Izz al-Din Ali ibn Mohammad Jarazi.(1989). Asad al-Ghabah in the knowledge of the companions. Beirut, DarAlfekr

Al-Hurr, Al-Amili, M. bin Al-Hassan. (1414AH). Shiite Means (Wasail al-Shia). Beirut, Dar Ihya Torath Al-Arabi

Al-Imad, A. al-Hayy bin ahmad bin M. (1998). Golden Nuggets in news from Gold. Beirut. Dar Ibn kathir

Al-kettani, M. Abdul-Hay. (1982). The Prophetic government system. Beirut, Dar Al Arqam

Al-Masudi. (2010). The Meadows of Gold. Translated by Paul Lunde.

Al-Suyuti. (1952). History of the Caliphs. Cairo, Alsaadah.

Amin, A. A. M. (1969). Fajr al-Islam. Beirut, Dar Al-Kitab Al-Arabi.

Amini, A. H., \& Refi al-Din, I. bin M. H. (1981). Al Ghadeer, The biography of the Prophet (PBUH). Translated by Asghar Mahdavi.

bn Majah. (2008). Sonnan.

Gue, L. S. (1958). Historical geography of the lands of the Eastern Caliphate. Translated by Mahmood Erfan. Tehran, Translation and Publishing Company.

Ibn Abd, al-Barr. (1421AH). Comprehensive expression of Knowledge and its Grace. Beirut, 
Dar Al-Kitab Al-Alamiya.

Ibn Khallikan. (1394AH). Shams al-Din Abu al-Abbas Ahmad ibn Ibrahim ibn Abi Bakr. Deaths of the Nobles. Eygept, Al-Saadah.

Ibn Rasta, I. (1985). Al-Alaq Al-Nafisa. Translated by Dr. Hossein Gharechanlo. Tehran, Amir Kabir Publication

Ibn, Saad, M. bin Saad bin Murea al-Basri. (2002). The great layered book. Beirut, Al-Khanki Library.

Maghazi, W. (1987). Kitab Al-Tarikh wa al-Maghazi. Translated by Mahmood Mahdavi Dammghani.

Quran. (2011). The noble Reading. The first American English Translation. International Publishing Co.

Rafi, al-Din I. Ibn M. H. (1981). The biography of the Prophet (PBUH). Translated by Asghar Mahdavi, Tehran.

Samhudi, A. A. (1419AH). Wafa Al-Wafa with the news of Dar Al-Mustafa. Beirut, Dar Kotob Al-Islamia.

Shlbi, A. (2006). Histiry of Education in Islam from the beginning to the collapse of the Ayyubids. Egypt, Translated by Muhammad Hossein Saket.

Subhi, S. (1414 AH). Nahj al-Balaghah, Hijra foundation. Iran, Qum

Wani, Z. A., \& Maqbool, T. (2012). The Islamic Era and Its Importance to Knowledge and the Development of Libraries. Library Philosophy and Practice (e-journal), 718.

Yaqubi, A. A. Y. (1353AH). Yaqubi History, Book of Countries. Translated by Dr. Mohammad Ibahim Ayati. Tehran

Zargani, M. A. A. (1988). The methods of mysticism in the sciences of the Quran. Beirut, Dar ehya Al-Torath Al-Arabia

Zayn, al-DIN al-Jubal Al' A. (1997). The meaning of the discipline in the literature. Bomby.

\section{Copyright Disclaimer}

Copyright for this article is retained by the author(s), with first publication rights granted to the journal.

This is an open-access article distributed under the terms and conditions of the Creative Commons Attribution license (http://creativecommons.org/licenses/by/3.0/). 